\title{
DESIGN OF A NOVEL EQUIPMENT FOR TREATMENT OF GREYWATER USING WOOD APPLE SHELL AS AN ADSORBENT
}

\author{
Kalyani Gaddam ${ }^{1, *}$ and Lakshmi Adathodi ${ }^{2}$ \\ ${ }^{1}$ Department of Chemical Engineering, GMR Institute of Technology, Rajam, AP, India \\ ${ }^{2}$ Department of Civil Engineering, RISE Group of Institutions, Valluru, Prakasam, AP, India \\ *E-mail: kalyani.g@ gmrit.edu.in
}

\begin{abstract}
In many arid and semi-arid countries, water is becoming an increasingly scarce commodity, and planners are forced to consider alternative sources of water that could be used efficiently and effectively for the order to promote further growth. Once greywater is recycled and reused in toilet flushing and irrigation, 35\% of water consumption in residential units can be minimized by simple technology. It is sewage from showers, pools, lavatories, washing machines and sinks. The wastewater from toilet usage, which is called black water, is not included in greywater. In the present study, novel equipment was designed to treat greywater (wastewater from kitchen sink) and be reused for irrigation and toilet flushing. It is portable equipment that will consist of three parts. Filter chamber, adsorbent columns and aeration chamber that consists of screening, alum bed, gravel bed, and sand bed. The adsorbent used here is a wood apple shell which has very good adsorption quality. It has a great affinity towards dye particles and heavy metals. It is very resourceful and novel equipment with low energy demand and is inexpensive so that even poor households can afford it. The treated water quality was checked against the guidelines for irrigation water quality given by the Bureau of Indian Standards and it was found to be in its permissible levels. It can, therefore, be inferred that the treated water can be used for irrigation or toilet flushing purposes.
\end{abstract}

Keywords: Greywater, Novel Equipment, Adsorbent, Wood Apple Shell, Flushing, Irrigation

@ RASĀYAN. All rights reserved

\section{INTRODUCTION}

Water is the elixir of life and the driving force of all nature. From the past few decades, there has been a great variation in the usage of water. Apart from irrigation and domestic purposes, water is mainly being used for industries, energy generation and other miscellaneous purposes. The growing population demands more energy generation and it will assume a much larger portion of water usage. Indian statistics say that by the year 2050 , the per capita availability of freshwater will be nearly 1447 cubic meters ${ }^{1,2}$ which highlights the fact that the future will be very difficult. Urban and industrial effluents are polluting rivers and groundwater that are India's primary source of irrigation and drinking. The quality of water continues to deteriorate. ${ }^{3}$ Water quality refers to the characteristics of a water supply that will influence its suitability for specific use by how well the quality suits the user's needs. Quality is defined by physical, chemical and biological properties. The current environmental strategies have pushed the research community to develop robust, economically feasible and environmentally friendly processes with an awareness of the importance of impacts due to the ability to remove pollutants from water.

To fight the water scarcity crisis, many ways have been discovered and technologies are being heavily funded to get a solution to it. The most ideal solution to it is wastewater treatment. The wastewater is daily generated in huge quantities and if not treated it causes environmental problems. Wastewater treatment and recovery is not only a considerable source of water that could possibly compensate the scarcity of freshwater encountered elsewhere, but is also beneficial in the situation that it is scientifically used for irrigation as it can act as a significant source of water and nutrients. ${ }^{4-6}$

Rasayan J. Chem., 13(1), 51-63(2019)

http://dx.doi.org/10.31788/RJC.2019.1245354 
Worldwide, the most common method for wastewater recycling is agricultural irrigation. ${ }^{7}$ Sewage, greywater and rainwater, where greywater is defined as domestic wastewater excluding toilet flush, are the potential sources identified for urban reuse. In some instances, mixed rain and greywaters were used as 'warm greywater' with only the bathroom sources. Greywater is a large source of low organic content and thus has the highest recycling benefit. In terms of reducing water consumption, recycling greywater also reduces the volume of water discharged into the wastewater system. ${ }^{8}{ }^{9}$ In many cases, several greywaters recycling ecological benefits can replace freshwater, save money and improve effective water supply in regions where irrigation is required. It is almost dependent on residential water for indoor and outdoor activities. Water could be recycled outside, achieving a better result with a decrease in the amount of water utilized by humans. Municipal treatment system can be optimized to a spectacularly high degree for the uppermost bioactive zone of the soil, which preserves the quality of natural surface and ground waters, by reducing the sewage flow, which in turn means greater treatment capacity and lower treatment costs. To clarify, greywater accounts for up to $70 \%$ of the total water produced but contains just $30 \%$ of the natural fraction and $9 \%$ to $20 \%$ of the nutrients. A variety of treatment methods are available with different degrees of purification to control and reduce water pollution.

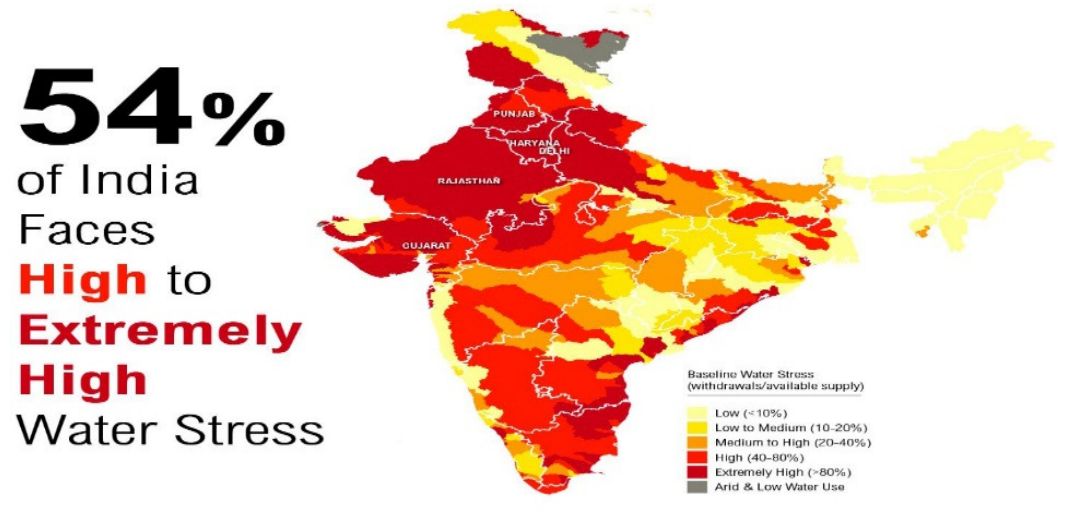

Fig.-1: Water Scarcity in India

(https://www.greenbiz.com/article/3-maps-explain-indias-growing-water-risks)

However, with the generation of toxic sludge, most of these methods involved complicated treatment procedures spending high operational and maintenance costs. ${ }^{10}$ With the advancement of technology, conventional methods are being modified to build cost-effective and environmentally friendly plants to improve waste reduction and give the desired output. Greywater management is not only a precondition for clean and healthy living conditions but also a great potential for reuse. Decentralized treatment of greywater is reused for a wide range of applications worldwide; the reuse of treated greywater for irrigation purposes is most common in developing countries. ${ }^{11,12}$ There are different strategies to treat wastewater in a decentralized way. Indeed, the decentralized process requires no large and capitalintensive sewer trunks, broadens the technological option variation, and has many advantages. The main aim of the project is to design equipment which will treat greywater (wastewater from kitchen sink) and be reused for irrigation and toilet flushing. It is portable equipment that will consist of three parts. First chamber - Filter chamber consists of following processes: screening, alum bed, gravel bed and sand bed. ${ }^{13}$ Here mainly the debris, suspended solids, froth, BOD, COD and undissolved metals are removed. The second chamber consists of adsorbent columns. The adsorbent used here is a wood apple shell which has very good adsorption quality. It has a great affinity towards dye particles and heavy metals. The last chamber is an aeration chamber where the foam fractionation process is carried out. ${ }^{13,14}$ Air bubbles are sent through the help of an air pump and all the remaining hydrophobic molecules are removed and treated clear water is procured through the outlet valve. The novel idea behind this is to minimize water wastage at every opportunity. Greywater constitutes a major part of wastewater and if it is possible to recycle and reuse it at the source only then probably water and money both can be saved. ${ }^{15,16}$ To promote inventories using technology that also is inexpensive, the material used for constructing the outer frame is Chlorinated polyvinyl chloride (CPVC). It is easily available and has good strength. The adsorbent 
columns can be easily removed so that the adsorbent can be easily replaced after its saturation. The aim of this work is to study the properties of greywater and the analyze the processes to be followed to treat the greywater collected and to design equipment which includes all these processes in one unit and is effective in treating it so that it can be reused for watering plants and toilet flushing. The unit can be easily installed in houses and offices.

\section{Source of Raw Greywater}

\section{EXPERIMENTAL}

The present investigation was conducted using greywater of GMRIT college staff quarters, Rajam, Srikakulam district, Andhra Pradesh. It is situated at an altitude of 18.28 North and 83.40 East longitudes. The minimum and the maximum annual average temperature at Rajam is $26^{\circ} \mathrm{C}$ and $45^{\circ} \mathrm{C}$, respectively; whereas relative humidity ranges from 45 to 60 percent. But the less water-retaining capacity of laterite soil during the summer months causes water scarcity. About 80 faculty members live in the allocated staff quarters. There are 5 wings in the quarters. These are three-story apartments with 24 flats in each wing. The sample was collected from one of the houses in the quarters. It was collected from the kitchen sink and the laundry outlet. There is no pre-treatment process carried out apart from normal screening. The big particles are removed off in this process. From that, the water will go directly to the inlet of the equipment.

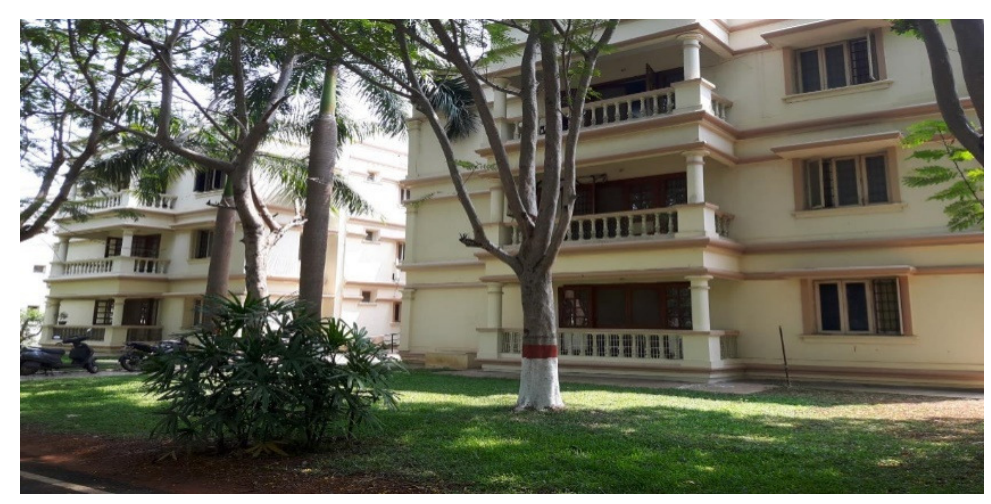

Characteristics of Greywater

Fig.-2: Experimental Site of GMRIT Staff Quarters

Greywater composition is varied according to the source of the greywater.

Table-1: Water Quality Characteristics of Domestic Greywater

\begin{tabular}{c|l}
\hline \multicolumn{1}{c}{ Water Source } & \multicolumn{1}{c}{ Characteristics } \\
\hline \multirow{3}{*}{ Sinks, including kitchen } & $\begin{array}{l}\text { Bacteria, Food particles, Hot water, Odour, Oil } \\
\text { and grease, Organic matter, Oxygen demand, Soaps, } \\
\text { Suspended solids, and Turbidity }\end{array}$ \\
\hline Bathroom and shower & $\begin{array}{l}\text { Bacteria, Hair, Hot water, Odour, Oil and grease, } \\
\text { Oxygen demand, Soaps, Suspended solids, and } \\
\text { Turbidity }\end{array}$ \\
\hline
\end{tabular}

\section{Physical Properties of Domestic Greywater Temperature}

Due to hot tap water used for personal hygiene and laundry, the temperature of greywater is often higher than the temperature of water supply. High temperature promotes microbial growth and in supersaturated waters contributes to calcite precipitation.

\section{Colour}

It is the greywater cloudiness caused by large quantities of individual particles.

\section{Turbidity and Contents of Suspended Solids}

It is a measure of water cloudiness, i.e. higher turbidity implies greater murkiness due to the presence of suspended solids in the liquid, which could potentially protect bacteria and improve the treatment loading. 


\section{Odour}

The anaerobic condition results in the removal of odorous compounds. It is generally non-offensive to consider the smell of untreated greywater.

\section{Chemical Properties of Domestic Greywater}

It is a general feature of greywater with certain nutrients (e.g. nitrogen, potassium) and microorganisms to contain the lower concentrations of organic matter. But there are nearly the same levels of heavy metals, ammonia, and xenobiotic organic contaminants. Chemicals such as laundry detergents, soap, shampoo, toothpaste and solvents are main sources of contaminants. Chemical demand for oxygen (COD) and biological demand for oxygen (BOD) content indicates the possibility of oxygen depletion due to the breakdown of organic matter during the transport process and storage with the threat of $\mathrm{S}^{2-}$ production, resulting terrible stench.

Table-2: Chemical and Physical Quality of Greywater Compared with Raw Sewage

\begin{tabular}{c|c|c|c|c}
\hline \multirow{2}{*}{ Parameter } & \multirow{2}{*}{ Units } & \multicolumn{2}{|c|}{ Greywater } & \multirow{2}{*}{ Raw Sewage } \\
\cline { 3 - 4 } & & Range & Mean & \\
\hline Suspended solids & $\mathrm{mg} / \mathrm{l}$ & $45-330$ & 115 & $100-500$ \\
\hline Turbidity & $\mathrm{NTU}$ & $22-200$ & 100 & Not applicable \\
\hline $\mathrm{pH}$ & & $6.5-8.5$ & 7.5 & $6.5-8.5$ \\
\hline Conductivity & $\mathrm{mS} / \mathrm{cm}$ & $325-1140$ & 600 & $300-800$ \\
\hline Hardness $(\mathrm{Ca}$ and $\mathrm{Mg})$ & $\mathrm{mg} / \mathrm{l}$ & $100-200$ & 150 & $200-700$ \\
\hline Nitrite & $\mathrm{mg} / \mathrm{l}$ & $0.1-0.8$ & 0.3 & $1-10$ \\
\hline Total phosphate & $\mathrm{mg} / \mathrm{l}$ & $0.6-27.3$ & 8 & $5-30$ \\
\hline BOD & $\mathrm{mg} / \mathrm{l}$ & $90-290$ & 160 & $100-500$ \\
\hline
\end{tabular}

As the variation is high in the chemical and physical performance of greywater generated by any household, the equipment is fabricated depending on those parameters. The locally available material is usually used in the construction of the machinery and the structure. The local expertise is generally used for operation and maintenance.

\section{Components of the Greywater Treatment System}

A wide variety of techniques have been applied worldwide for the treatment of greywater by varying both complexity and quality. The following are generally considered treatments:

\section{Primary Treatment}

Primary treatment is the first step used to remove most floating and settling contaminants in the treatment of wastewater. Primary treatment eliminates approximately $30 \%$ of the carbonaceous biochemical oxygen demand (CBOD) from domestic wastewater. Here there are two primary processes included-screening and alum bed.

\section{Secondary Treatment}

Bacteria ingest the organic parts of the waste during the second stage. It is achieved by mixing waste, bacteria and oxygen. Approximately 90 percent of the oxygen demanding materials are eliminated in the stage of testing, floating, settleable solids, suspended solids. The final stage of secondary treatment is disinfection. The three processes included in this treatment method are Gravel filtration bed, Sand filtration bed and Adsorption columns.

\section{Tertiary Treatment}

Advanced sewage cleaning that goes beyond the secondary or biological stage is the final treatment phase in which nutrients including phosphorus, nitrogen, and most BODs and suspended solids are extracted. A certain and separate system can accomplish each and every stage of treatment. The structures of the various treatment stages can be sequentially combined to achieve the necessary. 
RASĀYAN J. Chem.

Vol. 13 | No. 1 |51 - 63| January - March | 2020

Table-3: Classification of Systems Depending on the Treatment Stage

\begin{tabular}{c|c|c}
\hline Primary Treatment & Secondary Treatment & Tertiary Treatment \\
\hline Sedimentation pond & \multicolumn{2}{|c}{ Constructed Wetlands } \\
\hline Septic tank & Aerobic ponds & Maturation ponds \\
\hline Imhoff tank & Baffled septic tank & \\
\hline & Anaerobic bed filters & \\
\hline & Trickling filters & \\
\hline
\end{tabular}

\section{Common Methodologies}

There are many greywater treatment methodologies that can be followed to get reusable water. Some of these are as follows:

\section{Sand Filters}

Sand beds, coarse bark or mulch that trap contaminants and adsorb particulates as greywater flows through them. It's a simple process. Operating and service costs are comparatively very low but the capital cost is high. This cycle helps to reduce pathogens but does not remove them if they are overcharged due to obstruction and flooding.

\section{Membrane Bioreactor}

Aerobic biological treatment and filtration are used hand in hand to facilitate natural contaminant intake and filtration of all pathogens. Properly designed and operated bioreactors are highly efficient to have a high degree of flexibility in operations to handle greywater of varying quality and quantity. Properly designed and operated bioreactors are highly efficient to have a high degree of flexibility in operations to handle greywater of varying quality and quantity. It also allows for unlimited storage of treated water. However, capital costs, operating costs are high and operational requirements are also complex.

\section{Activated Carbon Filter}

To open millions of tiny pores between the carbon atoms, oxygen was used to treat activated carbon. Therefore, these filters are commonly used to adsorb colored or odorous compounds from gases or liquids. When properly designed and operated, it is highly effective in killing bacteria and its operation does not require highly skilled labor. It has high capital costs, for example, sodium, nitrates, etc., many other chemicals are not drawn to carbon at all.

\section{Disinfection}

Chlorine, ozone or ultraviolet light can all be used to disinfect greywater. It has highly effective in killing bacteria if properly designed and operated and low operator skill is a requirement. The main disadvantage is that chlorine and ozone can create toxic by-products. Based on variations in organic content of greywater, ozone and ultraviolet can be adversely affected.

\section{Aerobic Biological Treatment}

Greywater can be disinfected with chlorine, ozone or ultraviolet light. It is highly effective in killing bacteria when it requires properly built, controlled and low operator ability. The main disadvantage is that harmful byproducts can be formed by chlorine and ozone. It is possible to adversely affect ozone and ultraviolet depending on differences in the organic content of greywater.

\section{Technical Processes}

At the household level, the treatment of greywater mainly involves screening (removal of grease and silt), removal of soap froth and filtration. The household-based greywater treatment system is shown in the flow diagram below.

\section{Design of the Equipment}

The equipment is designed to consolidate all the primary, secondary and tertiary treatments in one unit. The upper chamber consists of both primary and secondary treatment systems. It consists of the screener, 
alum bed, gravel filter bed, and sand filter bed. The second chamber is further divided into two parts- the upper part is adsorbent columns chamber where there are two columns fitted that is filled with a natural adsorbent in such a way that it can be easily removed for adsorbent removal and regeneration. The lower part consists of aeration chamber where the foam fractionation mechanism is used to remove any other hydrophobic particles remaining in the water. The outlet tap is attached at the lower edge of the aeration chamber from where the treated water is collected. The design is done in AutoCAD.

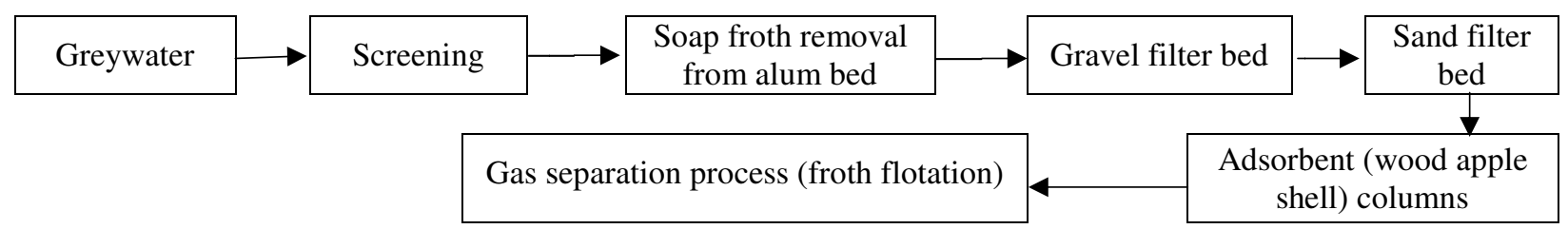

Fig.-3: Flow Diagram of Greywater Treatment Systems in the Equipment

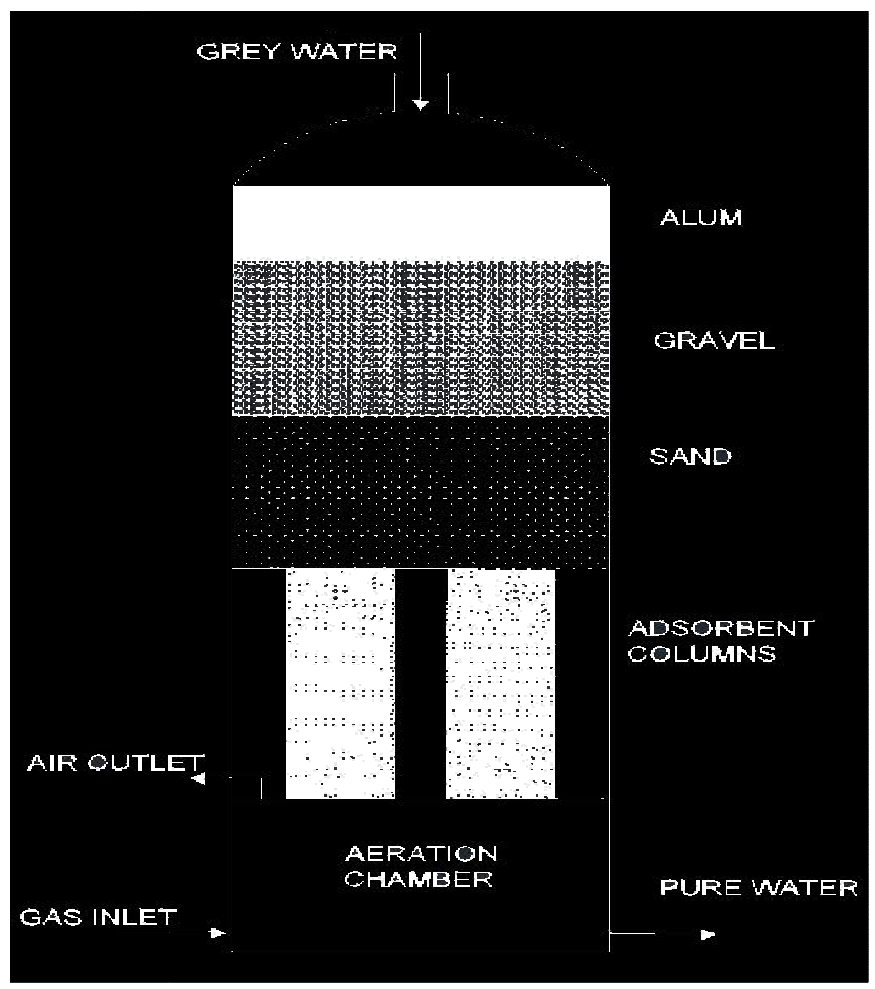

Fig.-4: Design of the Equipment

\section{Framework and Design Parameters}

For the outer framework of the equipment the material used is chlorinated polyvinyl chloride (CPVC) pipes. CPVC is a thermoplastic produced by chlorination of resin known as polyvinyl chloride (PVC) that is fundamentally more adaptable and can withstand higher temperatures than standard PVC. Uses include industrial liquid handling, hot- and cold-water pipes. CPVC, like PVC, is treated safely for the transport and utilization of potable water that is acceptable for drinking, cooking, and bathing. It can withstand corrosive water at temperatures typically by $40-50{ }^{\circ} \mathrm{C}\left(104-122^{\circ} \mathrm{F}\right)$ or higher which may be greater than normal PVC. It has better mechanical strength too. The equipment design is of cylindrical shape with a total height of $100 \mathrm{~cm}$ and $30 \mathrm{~cm}$ diameter. As water flows through the cylindrical tube, the pressure force is evenly distributed over the whole circumference of the pipe. For the total cross-sectional area, it requires the minimal product. A cylindrical tube has a minimal surface area that is exposed to air, so the water is drawn less when it flows down the pipe, reducing weight, etc. Therefore cylindrical shape is the ideal design and the most efficient in handling. 


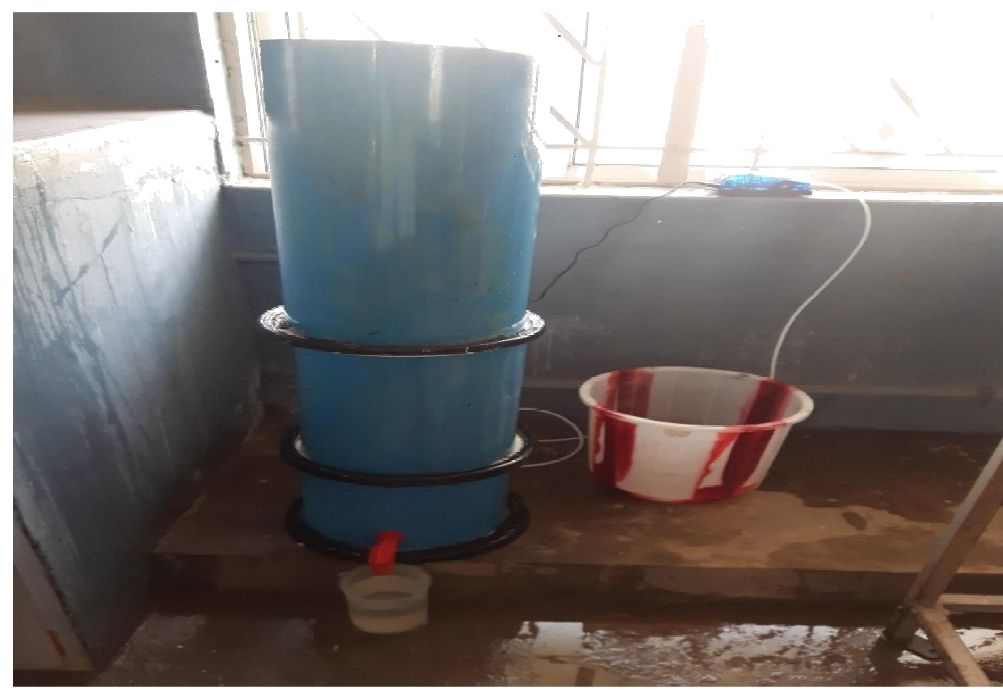

Fig.-5: Equipment Installation

Table-4: Dimensions of the Equipment

\begin{tabular}{l|l|c|c}
\hline \multirow{1}{*}{ Chamber } & Compartments & \multicolumn{2}{|c}{ Dimensions $(\mathrm{cm})$} \\
\cline { 2 - 3 } & & Height & Diameter \\
\hline \multirow{2}{*}{$\begin{array}{l}\text { Upper Chamber } \\
(50 \mathrm{~cm})\end{array}$} & Alum bed & 10 & \multirow{2}{*}{30} \\
\cline { 2 - 3 } & Gravel filter bed & 20 & \\
\cline { 2 - 3 } & Sand filter bed & 20 & \\
\hline \multirow{2}{*}{$\begin{array}{l}\text { Lower Chamber } \\
(50 \mathrm{~cm})\end{array}$} & Adsorbent column & 30 & 10 \\
\cline { 2 - 3 } & Aeration chamber & 20 & 30 \\
\hline
\end{tabular}

\section{Screening}

\section{EXPERIMENTAL}

Wastewater contains large solids and grit that can interfere with treatment processes or cause undue mechanical wear and increased maintenance on wastewater treatment equipment which require separate handling to minimize potential problems. Greywater contains suspended solids and some big insoluble molecules. Screening is the process that helps in removing all the floating particles like vegetable peels, insoluble solids, etc. The main advantage of using this approach is to protect the downstream structure against large objects that may cause obstructions in some of the units of the facility and may adversely affect and make their implementation more difficult. Equipment maintenance is very less or not required for manually cleaned screens and provides a good alternative for smaller plants with less screening procedure. A plastic sieve has been used in the equipment which has a very good mechanical strength and is effective in removing the solids.

\section{Alum Bed}

The alum is a chemical compound that is typically a hydrated double sulfate aluminum salt with the general formula $\mathrm{XAl}\left(\mathrm{SO}_{4}\right)^{2} 12 \mathrm{H}_{2} \mathrm{O}$ where $\mathrm{X}$ is a monovalent cation like potassium or ammonium. Alum is mostly used for the process of flocculation. It is a mechanism in which colloids come out of suspension in the form of a flake or floc either naturally or due to the addition of a clarifying agent. Colloids are merely suspended in a solvent before flocculation and not actually dissolved in a solution that differs from precipitation. With the use of flocculation polymers, electrically charged particles may also be precipitated. The particles that need to be flocculated the particles will be bound to the polymer combining them in larger particles, which cannot stay suspended and can be easily removed by using a polymer with the opposite charge. Here the polymer used is aluminium sulphate (alum). The objective of using the flocculation process is to remove turbidity and froth to a good extent. 
RASĀYAN J. Chem.

Vol. 13 | No. 1 |51 - 63| January - March | 2020

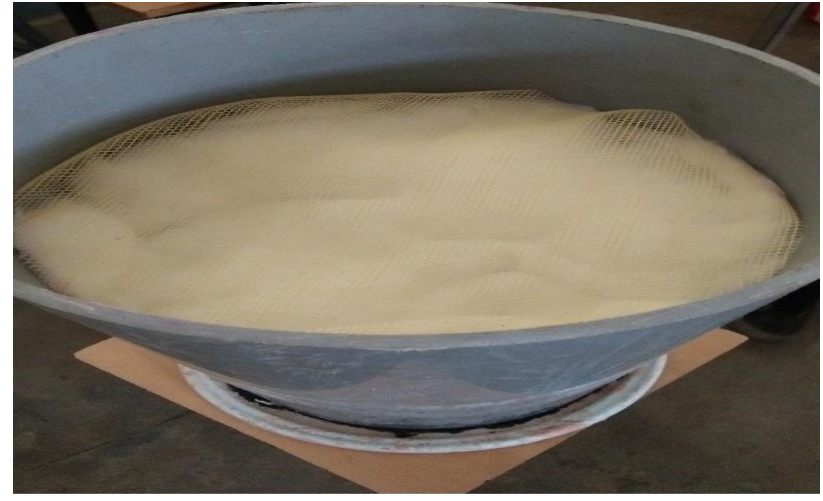

Fig.-6: Screening

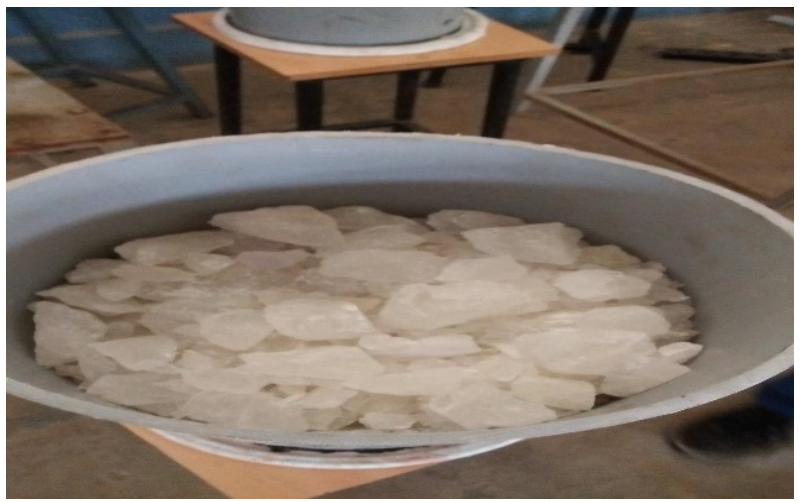

Fig.-7: Alum Bed (10 cm depth)

\section{Gravel Filter Bed}

Gravel is a fragmented granular piece of any rock type. Gravel is usually between $2 \mathrm{~mm}$ and $40 \mathrm{~mm}$ in size. The selected gravel size was between 15 and $25 \mathrm{~mm}$. They could be rounded when quarried and crushed from a marine or fluvial base or angular source. It gives support to other media. Debris, particles, water sediments and deposit material in between gravel grains are captured and removed by gravel beds where millions of microbes (beneficial bacteria) can now be further broken down on the gravel bed surface that filters wastewater. So it has a large impact on water clarity and quality.

\section{Sand Filter Bed}

The sand used in the filters must be hard and dust-free. It should be resistant to chemical attack. It is insoluble, hard, silica and is not supposed to have clay, silt and dust. Sand filtration is used primarily to remove suspended matter, as well as floating and sinkable particles, where the wastewater flows vertically through a fine sand bed. Through absorption or physical encapsulation, particles are removed.

Sand filtration is usually used to remove suspended matter, COD, BOD, organically bound nitrogen and phosphate, and undissolved metals. The local sand was properly screened and used as filter media. After screening it into coarse and fine sand sizes, it was washed properly and layered from the top with sand of size ascending order that is first fine sand layer was filled and then gradually big size sand was added.

\section{Adsorbent Columns}

Two-phase interface, such as liquid-liquid, gas-liquid, gas-solid or liquid-solid, is an adsorption mass transfer process that involves the accumulation of substances at the interface. The adsorbed product is the adsorbate and the adsorbing material is considered as the adsorbent. Characteristic properties of adsorbents and adsorbates are very specific and depend on their constituents. Activated carbon is one of the most active media and known as the most efficient adsorbent in the world that can eliminate a wide range of contaminants from industrial, municipal wastewaters, landfill leachate, and polluted groundwater. There may be different contaminants in the same discharge and carbon may be used to treat the total flow and as part of a multistage approach, it may be better utilized to remove specific contaminants. Agricultural solid waste is a good source of adsorbent which is cheap and readily available. There are many such sources like agave bagasse, almond shell, mango peel waste etc. that can be turned into activated carbon to act as a strong adsorbent. But there are some solids which naturally have good adsorbing properties. The bio sorbent we used for our study is Wood Apple Shell (WAS).

\section{Wood Apple Shell (WAS)}

The wood apple (Feronia acidissima) contains polar functional groups such as alcoholic, carboxylic and ether. Wood Apple is also a native and common fruit grown in India, Sri Lanka, Thailand, and Cambodia's dry plains. There is a lot of medical significance for parts like bark, leaves, and wood apple tree fruits. The disposal of large quantities of shells directly into the soil may contaminate the ecosystem in an uncontrolled manner as the decomposition of this waste material contributes to the production of 
different chemical compounds and microorganisms. Therefore, with the preparation of biosorbent from wood apple shell dust, there are many economic and environmental benefits for developing countries like India.

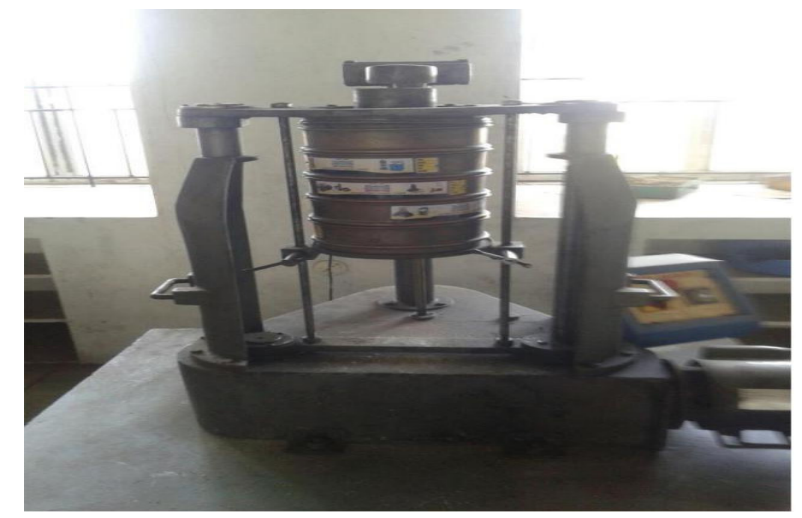

Fig.-8: Sieving Sand in Rotap Sieve Shaker

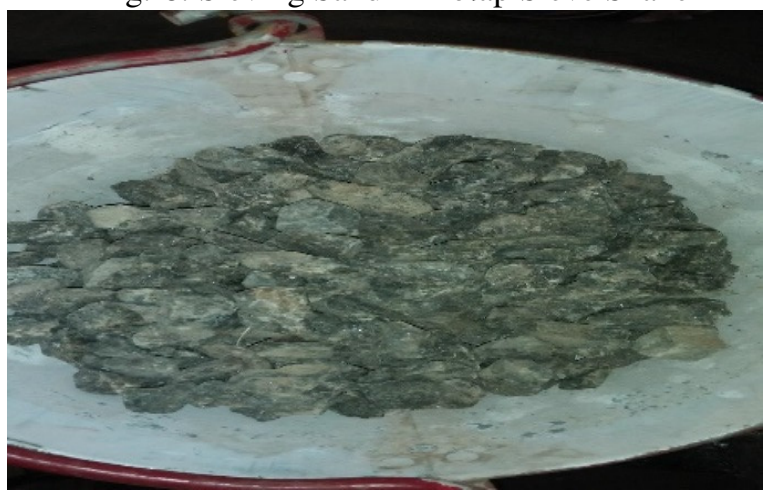

Fig.-10: Gravel Filter Bed (20 cm Depth)

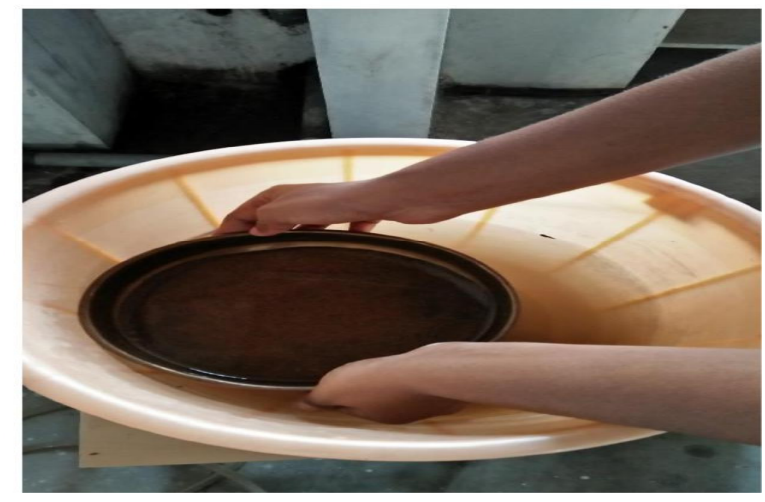

Fig.-9: Cleaning of Sand Media

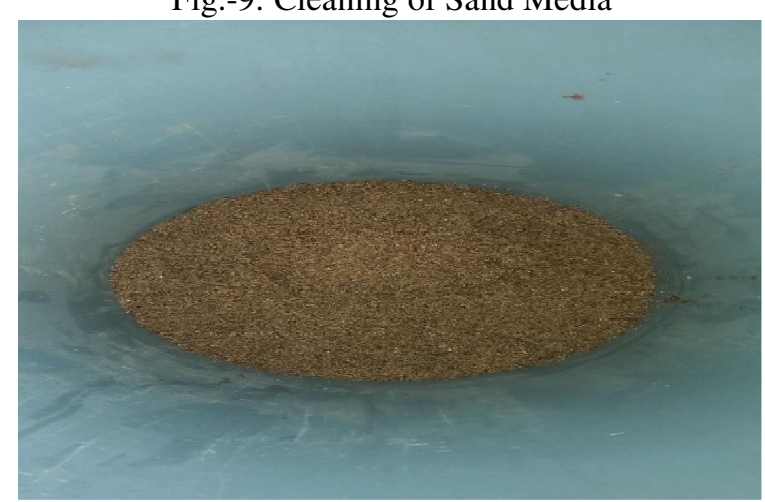

Fig.-11: Sand Filter Bed (20 cm Depth)

\section{Preparation of Wood Apple Shell (WAS)}

Wood apple shells ere nicely cleaned with water and dried under sunlight for 24 hours till it becomes very dry. After that to reduce its size too small pieces it is put into jaw crusher. These pieces are further powdered into fine to a little coarse sized particles with the help of attrition mill. It is sieved properly in $100 \mathrm{~nm}$ mesh. The powder is once again washed till distilled water to remove any colored particle. It is then given an acid bath by using $\mathrm{H}_{2} \mathrm{SO}_{4}$ for 2-3 hours. Again the WAS powder is washed in distilled water to get normal $\mathrm{pH}$. Dry the powder in an oven for $110^{\circ} \mathrm{C}$ for nearly 24 hours till it is completely dry. The adsorbent is ready to use.

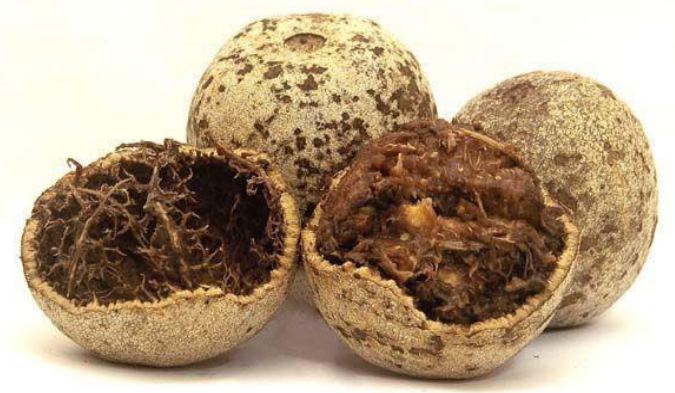

\section{Aeration Chamber}

Fig.-12: Wood Apple Shell

Wastewater aeration is the method of adding air into wastewater to allow aerobic biodegradation of pollutants and is a well-known integral part of most biological wastewater treatment systems. The biological treatment uses natural microorganisms in wastewater to degrade sewage contaminants whereas 
chemicals are used to react and stabilize contaminants in the wastewater streams in chemical treatment. In this equipment, the aeration chamber is fixed in the lower chamber at the end. To provide air, the electric air pump is used. The mechanism followed is foam fractionation.

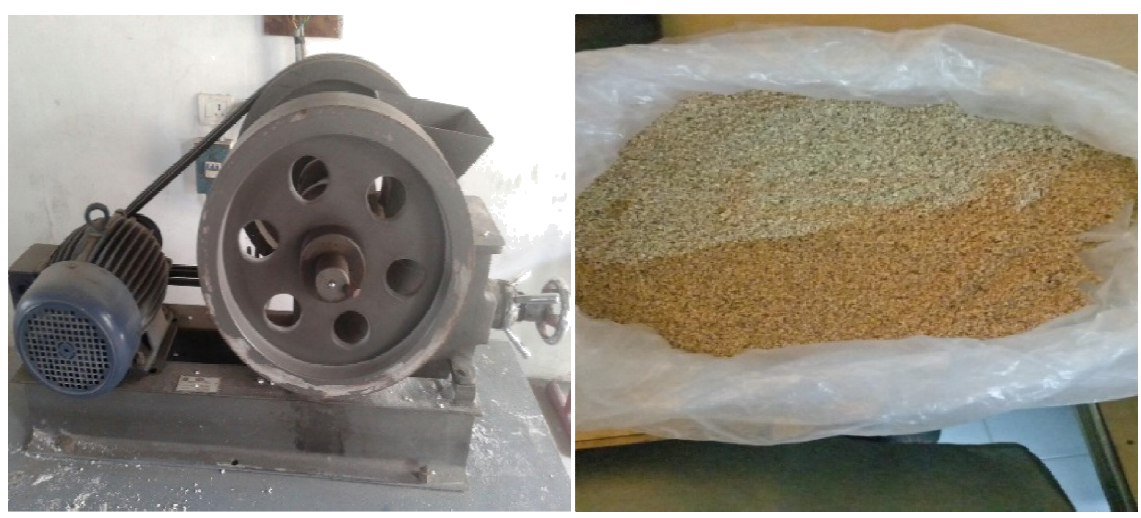

Fig.-13: Jaw Crusher

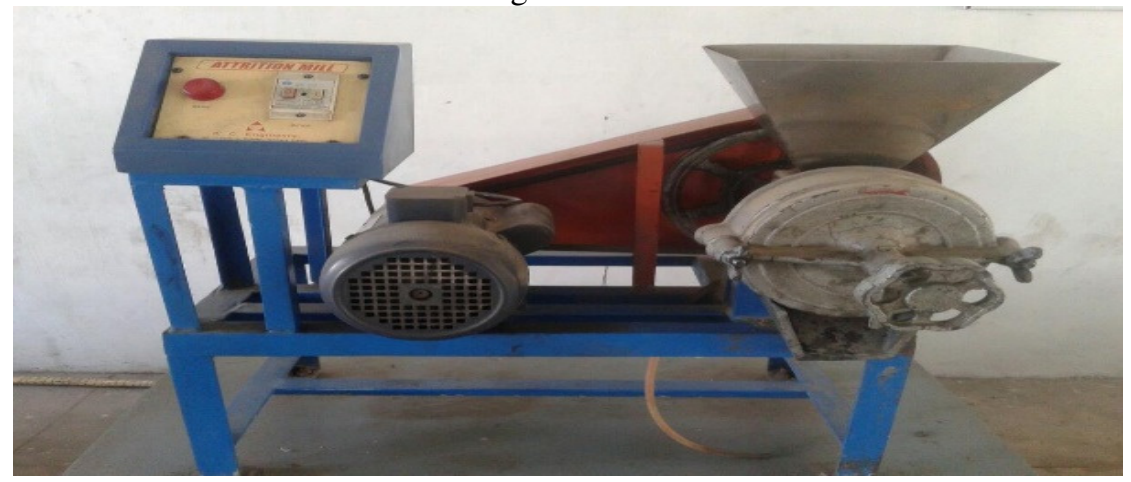

Fig.-14: Attrition millFig.-15: WAS Adsorbent

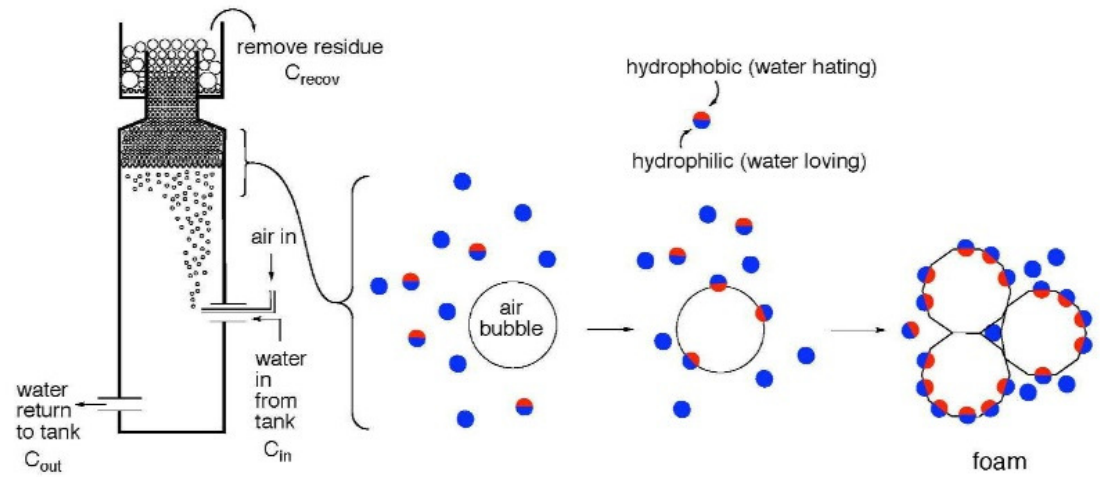

Fig.-16: Foam Fractionation Mechanism Used in the Aeration Chamber

Hydrophobic molecules are usually removed from a liquid solution using rising foam columns in the chemical process of foam fractionation. It is widely used for the extraction of organic waste from aquariums. It is commonly used for the removal of organic waste from aquariums. In this equipment, foam fractionation is used to remove any hydrophobic molecules which may have travelled from the above filtration media and adsorption columns.

\section{pH}

\section{RESULTS AND DISCUSSION}

The chemical and biological properties of fluids make their determination very significant with the effect of $\mathrm{pH}$. It is the most important parameter in water chemistry and is defined as $-\log \left[\mathrm{H}^{+}\right]$, and the acidity or 
alkalinity strength is measured on a scale ranging from 0-14. It can be expressed as the ions are of acidic nature if there are excess free $\mathrm{H}^{+}$ions (i.e. $\mathrm{pH}<7$ ), while the presence of more $\mathrm{OH}^{-}$ions (i.e. $\mathrm{pH}>7$ ) indicates that the ions are of alkaline nature. In natural water, $\mathrm{pH}$ is regulated by the equilibrium between ions of carbon dioxide/bicarbonate/carbonate and ranges from 4.5 to 8.5, though most basic. For irrigation water quality analysis, $\mathrm{pH}$ is usually a standard measurement. It is measured using a pH meter.

\section{Turbidity}

It is a measure of water cloudiness, i.e. higher turbidity implies greater turbidity due to the presence of suspended solids in the liquid, which could theoretically protect bacteria and enhance the treatment loading. It has been measured by turbidity meter. Water turbidity is considered as a more meaningful measure when a light beam propensity of particle scatters a light beam focused on them. It is measured using an instrument called a nephelometer where the detector is mounted on the side of the beam of light. If the source beam is filled with lots of small particles, more light will enter the detector than if there are none. The units of turbidity are denoted by Nephelometric Turbidity Units (NTU).

Table-5: Parameters and Obtained Results

\begin{tabular}{c|c|c}
\hline Properties & Before treatment & After treatment \\
\hline $\mathrm{pH}$ & 7.5 & 7.3 \\
\hline Turbidity & $150 \mathrm{NTU}$ & $5 \mathrm{NTU}$ \\
\hline Conductivity & $250 \mathrm{mS} / \mathrm{cm}$ & $20 \mathrm{mS} / \mathrm{cm}$ \\
\hline Total Suspended Solids & $200 \mathrm{mg} / \mathrm{l}$ & $10 \mathrm{mg} / \mathrm{l}$ \\
\hline Hardness & $320 \mathrm{mg} / \mathrm{l}$ & $220 \mathrm{mg} / \mathrm{l}$ \\
\hline Phosphates & $1.95 \mathrm{mg} / \mathrm{l}$ & $1.825 \mathrm{mg} / \mathrm{l}$ \\
\hline Nitrates & $0.8 \mathrm{mg} / \mathrm{l}$ & $0.76 \mathrm{mg} / \mathrm{l}$ \\
\hline COD & $380 \mathrm{mg} / \mathrm{l}$ & $58 \mathrm{mg} / \mathrm{l}$ \\
\hline BOD & $180 \mathrm{mg} / \mathrm{l}$ & $35 \mathrm{mg} / \mathrm{l}$ \\
\hline
\end{tabular}

\section{Conductivity}

Conductivity (specific conductance) is the numerical expression of the water's ability to conduct an electric current. It is measured in micro Siemens per $\mathrm{cm}$ and depends on the total concentration, mobility, valency and the temperature of the solution of ions. It imparts by the electrolytes in a solution that disassociates into positive (cations) and negative (anions) ions. Most dissolved inorganic substances are in the ionized form in water and contribute to conductance. The rapid and practical estimate of the variation in dissolved mineral content of the water supply gives the conductance value. It is defined as the reciprocal of the resistance involved and is measured using conductivity meter that expressed as mho or Siemen (s).

\section{Total Suspended Solids (TSS)}

Total solids (also referred to as total residues) are termed as the material left in a container after evaporation and drying of a water sample. Total Solids contain all total suspended solids, the amount that passes through a filter, the fraction of total solids retained by a filter and total dissolved solids. High TSS can block light from submerged vegetation. When the amount of light passing through water is decreased, photosynthesis slows down and allows plants to release less dissolved oxygen into the water. The plants will stop producing oxygen and die if the light from the bottom-dwelling plants is completely blocked. As the plants are decomposed, the bacteria will use even more oxygen from the water Low dissolved oxygen (DO) can result in the killing of fish. As the suspended particles absorb heat from sunlight, high Total Suspended Solids can also cause an increase in surface water temperature. This can cause the levels of dissolved oxygen to drop even further and in many other ways can destroy aquatic life. A weighted dish can be used to measure total suspended solids (SS) by evaporating a water sample and then drying the residue in an oven at $103{ }^{\circ} \mathrm{C}$ to $105{ }^{\circ} \mathrm{C}$. The change in dish weight represents the total volume of suspended solids in the sample.

\section{Hardness}

Water hardness is an aesthetic water quality which is mostly caused by calcium and magnesium minerals, but is classified and determined based on calcium carbonate concentration levels. Hardness does not 
directly affect plants, but hardness caused by bicarbonates can affect soils, thereby affecting plant growth indirectly. Calcium salts can also form a white lime (calcium carbonate) encrustation. Such deposits gradually obstruct the machinery for irrigation and therefore need to be minimized.

\section{Phosphates}

Phosphate containing compounds in the past have been used in detergent formulations as water softeners and hence these are among the greatest contributors to phosphate content in lakes and rivers because. Phosphate is not toxic to plants or animals, in fact, it is a plant nutrient that stimulates the growth of algae and aquatic weeds. This may cause lakes and rivers to become clogged and overrun with plants. This method involves the formation of molybdophosphoric acid, which reduces the intensely colored complex of molybdenum blue.

\section{Nitrates}

Nitrate ions observed in the samples of freshwater are generated from natural and artificial sources. These are the crucial source of nitrogen and an essential element for the synthesis of amino acids and proteins by plants and animals. Anthropogenic nitrate sources may increase levels above $3 \mathrm{mg} / \mathrm{l}$ whereas freshwater nitrate levels are normally below $1 \mathrm{mg} / \mathrm{l}$. Nitrate rates sources include feedlots of cattle, runoff from fertilized fields, and treated municipal wastewater which return to rivers and reservoirs. The test mentioned here is used to measure the concentration of $\mathrm{NO}_{3}{ }^{-}$and nitrate ions in a water sample. The nitrate concentration is measured in $\mathrm{mg} / \mathrm{l} \mathrm{NO}{ }_{3}{ }^{-} \mathrm{N}$ units and it is in the form of nitrate is in the $\mathrm{NO}_{3}{ }^{-} \mathrm{N}$ group. The spectrophotometric method is used here to the determination of nitrates in the sample.

\section{Chemical Oxygen Demand (COD)}

The amount of oxygen in a given solution that can be absorbed by reactions indicates the presence of chemical demand for oxygen (COD). It is commonly expressed in oxygen mass consumed over the volume of solution estimated in $\mathrm{mg} / \mathrm{l}$. It is easy to quantify the amount of organics in water through the COD analysis. COD's most common use is to quantify the amount of oxidizable pollutants found in surface water or wastewater. The COD test is useful for determining the water quality by providing a measure to calculate the impact, an effluent will have on the receiving body.

\section{Biochemical Oxygen Demand (BOD)}

Biological oxygen demand also termed as Biochemical oxygen demand is the amount of dissolved oxygen (DO) that is needed by aerobic biological organisms to break down organic material content presents in the water sample at a specific time period and certain temperature. The BOD value is most commonly expressed in $\mathrm{mg}$ of oxygen absorbed per litre of the sample during 5 days at $20{ }^{\circ} \mathrm{C}$ incubation and is widely used to determine the level of organic pollution. The effectiveness of wastewater treatment plants may be determined by the presence of BOD.

\section{Discussions}

According to the observations and calculated values of different parameters, there have been substantial changes in the inlet and outlet water quality. Out of all the given tests conducted, there has been a huge reduction in turbidity, conductivity, TSS, COD and BOD. Other minute changes were observed in the $\mathrm{pH}$, hardness, phosphates and nitrates. Apart from chemical properties, certain physical properties such as temperature, colour and odour. The temperature was observed to increase a little after treatment. Odour of the untreated water sample was found to be non-offensive and after treatment, the odour had almost disappeared. So was the case with foam. As it can be seen in Fig.-4.17, foam and turbidity has been almost removed totally. The water quality has been checked based on the standard tests described in the guidelines for water quality monitoring laid down by the Central Pollution Control Board (CPCB). On the basis of the test results, a comparative analysis (Fig.-18) has been made between the untreated greywater sample and the treated one collected from the outlet of the equipment. This shows the margin of changes in each parameter in numerical values. 


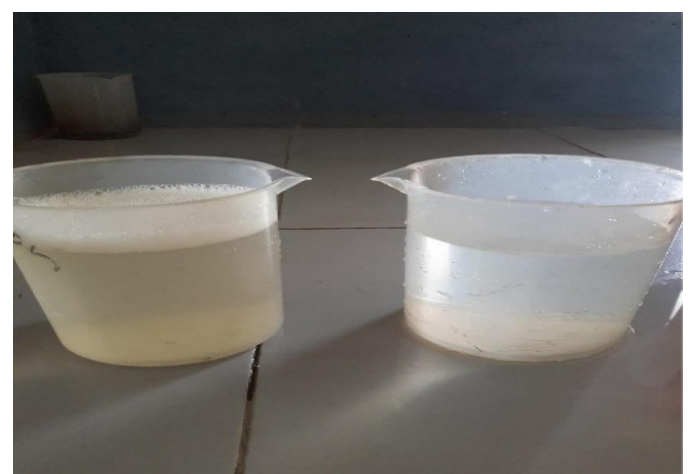

Fig.-17: Untreated and Treated Water Sample

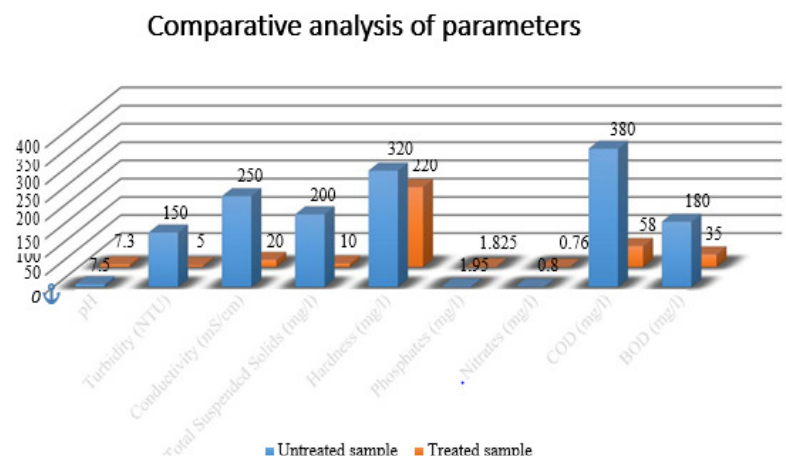

Fig.-18: Comparative Analysis of Water Parameters

\section{CONCLUSION}

The main aim behind this project was to find a solution to minimize wastage of greywater particular waste water from kitchen sinks and laundry outlets at the generation level itself i.e., at houses and offices. Keeping in mind the technicalities of the treatment processes, an equipment was designed that is very portable and economically feasible along with having no negative effect on the environment. All the materials used are locally available and readily usable. The framework of the equipment is designed in a feasible manner such that the regeneration of filter media and adsorbent is easy. The labor and operational costs incurred are very low. The treated water sample was collected from the outlet of the equipment. Its water quality was checked against the guidelines for irrigation water quality given by the Bureau of Indian Standards and it was found to be in its permissible levels. Thus can be concluded that the treated water can be used for irrigation purpose and toilet flushing. The benefits found are of low energy demand and its efficiency can be increased by more treatment like chlorination, ultraviolet rays, etc. It is a very resourceful and novel equipment and is inexpensive so that even poor households can afford it.

\section{REFERENCES}

1. D. Sahar and Bark, Swedish University of Agricultural Sciences, 11(2), 147(2013).

2. N. Zaidun, J. for Engg Sciences, 4(5), 225(2011).

3. I.L. Hussain, M.A. Raschid and W. VanderHoek, J. for Tech impacts and methodologies, 37, 10(2002).

4. H. Joga Rao, P. King and Y. Prasanna Kumar, Rasayan Journal of Chemistry, 11(3), 1376(2018), DOI: $10.31788 /$ RJC.2018.1134035

5. G. Kalyani, Y. Prasanna Kumar and P. King, Rasayan Journal of Chemistry, 9(3), 510(2016).

6. A. Lakshmi, J. Raja Murugadoss and G. Kalyani, Rasayan Journal of Chemistry, 11(3), 1204(2018), DOI: $10.31788 /$ RJC.2018.1134009

7. J.K. Borchardth, J. of Poten. Analogies, 2, 47(1994), DOI:10.1016/0927-7757(94)80081-2.

8. A.Lakshmi, J. Raja Murugadoss and G. Kalyani, Internat J. of Mech. and Production Engg. Res. and Development, 8(2), 1227(2018), DOI:10.24247/ijmperdapr2018141.

9. E. Erikson, K. Auffarth, M. Henze and A. Ledin, J. of Urban Water, 4, 85(2002), DOI:10.1016/S1462-0758(01)00064-4.

10. H. Lukas, D. Stefan, G. Rostom and W. Claudia, J. of Tech Solution for Sustainable Wastewater, Management, 4, 10(2015).

11. Uveges, N. Boros, L. Ungvari and I. Bodnar, J. of Recent advances in Env and Bio Engg, 4, 43 (2013).

12. A. Imhoff and M. Joel, J. of State. Art., 11, 58(2005).

13. G. Kalyani, Y. Prasanna Kumar and P. King, International Journal of Current Research, 8(2), 26048(2016).

14. R. Crites and G. Tchobanoglous, J. of McGraw Engg., 2, 21(1998).

15. A. Aminesh and G. Puneet Kumar, Internat J. of Advanced Research, 3, 412(2015).

[RJC-5354/2019] 